\title{
Culture alternative medium for the growth of extreme halophilic bacteria in fish products
}

\author{
Meio de cultura alternativo para o crescimento de bactérias halofílicas extremas em produtos de pesca
}

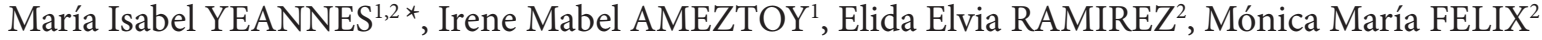

\begin{abstract}
Halotolerant or halophilic (Archaeabacteria) microorganisms can be found in salted and ripening fish products that are not affected by salt. They can be moderate or extremely halophilic bacteria. The extremely halophilic bacteria require between $15-30 \%$ of $\mathrm{NaCl}$ for growth. The extremely halophilic archaeobacteria may be selectively isolated in different media. The aim of this work was to determine the effectiveness of the Salt-Agar-Milk medium, a medium modified in our laboratory through the addition of $\mathrm{MgSO}_{4}$ and $\mathrm{KCl}$ - named SAMm, and its effect on the bacterial growth by means of comparison with other media, with and without milk, determining time of incubation and counting. Two samples of salted fish from local fish salting factories and two laboratory strains were used. The factory samples were matured anchovy and anchovy fillets in oil, and the laboratory strains were: Haloarcula spp. (proteolytic) and Halococcus spp. (non-proteolytic). The following media were alternatively used for the isolation of extremely halophilic bacteria: IRAM; Formulation of Gibbons and collaborators, Cod Milk agar, and SAMm. IRAM and Gibbons were also used enriched with milk. In the SAMm medium, there were obtained count values similar or higher than the ones of the traditional media; besides the simplicity of its elaboration, the possibility to obtain positive results two or three days earlier also added to its benefit. Consequently, it can be considered an alternative to the media traditionally used for the studied halophilic bacteria.
\end{abstract}

Keywords: Archaeobacteria; culture media; food; salted products.

\section{Resumo}

Em produtos de pesca salgados e maturados são encontrados micro-organismos halotolerantes ou halofílicos (archaeobactéria) que não são afetados pelo sal. Eles podem ser bactérias halofílicas moderadas ou extremas. As bactérias halofílicas extremas requerem entre $15 \%$ e $30 \%$ de $\mathrm{NaCl}$ para o crescimento. As archaeobactérias halofílicas extremas podem ser seletivamente isoladas em diferentes meios. O objetivo deste trabalho foi determinar a efetividade do meio Sal-Ágar-Leite, um meio modificado em nosso laboratório com a adição de $\mathrm{MgSO}_{4} \mathrm{e}$ $\mathrm{KCl}$ (nomeado SAMm), e seu efeito em crescimento bacteriano por meio da comparação com outros meios com e sem leite. Duas amostras de peixe salgado em fábricas de salgadura de peixe locais e duas cepas de laboratório foram usadas. As amostras de fábrica foram anchova maturada e filetes de anchova em óleo e as cepas de laboratório foram: Haloarcula spp. (proteolítico) (PC) e Halococcus spp (não proteolítico). Os seguintes meios foram usados alternativamente para o isolamento de bactérias halofílicas extremas: IRAM, Formulação de Gibbons e colaboradores, ágar de Bacalhau com Leite e SAMm. IRAM e Gibbons também foram usados enriquecidos com leite. Com o meio SAMm, os valores da recontagem foram semelhantes ou mais altos que com os meios tradicionais, a possibilidade de se obter resultados positivos dois ou três dias antes também acrescentam seus benefícios além da simplicidade de sua preparação. Por conseguinte, poderia ser considerada uma alternativa para os meios tradicionalmente usados para estudar bactérias halofílicas extremas.

Palavras-chave: Archaeobactérias; meio de cultura; alimento; produtos salgados.

\section{Introduction}

Fish are highly perishable and will spoil rapidly if improperly handled. There are several preservation methods to avoid fish spoilage and the growth of pathogenic microorganisms, among them salting is a method that has been used for centuries and in many places around the world such as Asia, Europe, Africa and Latin America (HUSS, 1994; WANG et al., 2000; YEANNES, 2006; MADUREIRA et al., 2007; DORÉ, 2008; LEE; RANGDALE, 2008, SCHMIDT, et al., 2009). The simplicity of the salting process, its low production cost and the ease of combining it to other preservation methods, such as marinades, ripening, drying or smoking, has led to its popularity and extensive use (FUSELLI et al., 1994, 2003; YEANNES; CASALES, 1995, 2008).

At certain concentrations, salt was found to prevent growth of many microorganisms creating an environment unsuitable for microbial proliferation but some halotolerant or halophilic (archaeabacteria) microorganisms are not affected by salt (SORTE; JAGER, 1997; BARAT et al., 2003; BELLAGHA et al., 2007). The archaeabacteria represent the third line of descent in the evolution of life. This definition is based mainly on sequence comparisons of the $16 \mathrm{~S}$ rRNA by Woese et al. (1990), and they are clustered into five major groups: methanogenic

Received 9/8/2008

Accepted 14/2/2010 (003698)

${ }^{1}$ Consejo Nacional de Investigaciones Científicas y Tecnológicas - CONICET, Centro Científico y Tecnológico Mar del Plata, Argentina, e-mail: myeannes@mdp.edu.ar

${ }^{2}$ Grupo de Investigación Preservación y Calidad de Alimentos, Departamento de Ingeniería Química, Facultad de Ingeniería, Universidad Nacional de Mar del Plata

${ }^{*}$ Corresponding author 
archaebacteria, archaebacterial sulphate reducers, extremely thermophilic sulfur metabolizers, cell wall-less archaebacteria, and extremely halophilic archaebacteria (KONIG; STETER, 1994; WOESE, 2000; ELSZTEIN et al., 2001).

A microorganism is named halophilic when it needs salt concentration higher than the sea water one for its development. Halophilic bacteria have suffered an adaptative evolutionary process and their physiology was definitively modified to grow and survive in this environment (MONTERO et al., 1991). They can be moderate or extreme halophilic bacteria. The moderate halophilic bacteria require 5-10\% salt concentration for their optimal growth, and the extreme ones require between 15-30\% (KONIG et al., 1989). Taxonomically, they are included in the Halobacterials order with only one Family, Halobacteriaceae. (Ventosa et al., 1999; Woese, 2005).

This kind of bacteria is very important in salted foods (FELIX et al., 2004, 2005; YEANNES et al., 2005; SÁNCHEZ LEAL; ARGUELLO ARIAS, 2006). The presence of extremely halophilic bacteria in foods gives them a reddish coloration; sometimes causing odours and textural changes that promotes rejection by consumers (HERNANDEZHERRERO et al., 1999; DORÉ, 2008; RAMIREZ; SERRANO; SANDOVAL et al., 2006; YEANNES, 2006).

Halophilic bacteria are natural contaminants in salt used in preserving fish (FELIX et al., 2007a); the good shelf stability of salt fish produced can be affected to the quality of the salted used. Since the time of anchovy ripening is long and these bacteria can have proteolytic and lipolytic characteristics, their growth can produce unwished changes; therefore, the determination of halophilic bacteria content is an important matter in salted products (CZERNER; YEANNES 2007).

The extreme halophilic archaeobacteria may be selectively isolated in different media, e.g., formulation of Gibbons et al. (hereafter Gibbons agar) (KONIG; STETER, 1994), INSTITUTO ARGENTINO DE NORMALIZACIÓN Y CERTIFICACION (1988), CMA (cod milk agar) (BALLABENE et al., 1979). In these media the bacteria require about 8-12 days for their growth Instituto Argentino de Normalización y Certificacion (1988). Besides, it is important to consider that the preparation in laboratory of these media is complex.

Ramirez et al. (2001) and Felix et al. (2002) showed that a fast and good growth of halophilic bacteria was obtained in the medium employed to determine the proteolytic characteristic of eubacteria (Agar-Milk) (INTERNATIONAL DAIRY FEDERATION, 1974) added with ClNa (Salt- Agar- Milk, henceforth named SAM). Taking these results into account, considering that CMA medium contains milk in its formulation and that the growth requirements for these bacteria are particularly demanding in terms of nutrients; in this work, it was also considered whether a milk enrichment of the IRAM and Gibbons media would improve their development.

According to Gibbons (KONIG; STETER, 1994), K and $\mathrm{Mg}$ ions are required for the growth of these bacteria; therefore, $\mathrm{MgSO}_{4}$ and KCL were added to the SAM medium. The modified medium (SAMm) was compared to the latter media frequently used in halophilic bacteria culture. Experiments with the laboratory strains: Haloarcula spp. (proteolytic) and Halococcus spp. (non-proteolytic) were carried out, also with samples of salted anchovy and oil anchovy fillets obtained from salting factories, in order to observe the relevance of interspecific competence in the growth of these microorganisms.

The aim of this work was to determine the effectiveness of the SAMm medium on bacterial growth, comparing it with the other media used for halophilic bacteria, and considering whether a milk enrichment of the IRAM and Gibbons media would improve their development.

\section{Materials and methods}

Studies of alternative different media for isolation and counting of extremely halophilic bacteria have been carried out in our laboratory.

Two different types of samples of salted fish from local fish salting factories and two different types of laboratory strains were used. The factory samples were of matured anchovy with eight months of ripening time (40 samples) and of anchovy fillets in oil (30 samples). The laboratory strains were: 10 samples of Haloarcula spp. (proteolytic) (PC) and 10 samples of Halococcus spp. (non-proteolytic) (NPC). These strains were isolated in laboratory and obtained from salted fish products.

The three complex media were alternatively used for the isolation of extremely halophilic bacteria.

The agar media used were composed by:

- Tryptone, $5 \mathrm{~g}$; $\mathrm{NaCl} 200 \mathrm{~g}$; $\mathrm{SO}_{4} \mathrm{Mg}+7 \mathrm{H}_{2} \mathrm{O} 20 \mathrm{~g}$; Yeast extract 4 g; Agar $17 \mathrm{~g}$; $\mathrm{KCl} 5 \mathrm{~g}$; $\mathrm{CaCl}+6 \mathrm{H}_{2} \mathrm{O} 0.2 \mathrm{~g}$. $\mathrm{pH}$ 7.0-7.2 (INSTITUTO..., 1988) - named IRAM in this work for practical purposes.

- Trisodium citrate $3 \mathrm{~g} ; \mathrm{NaCl} 200 \mathrm{~g} ; \mathrm{SO}_{4} \mathrm{Mg}+7 \mathrm{H}_{2} \mathrm{O} 20 \mathrm{~g}$; yeast extract $10 \mathrm{~g}$; Agar $20 \mathrm{~g}$; $\mathrm{KCl} 2 \mathrm{~g}$; casein hydrolysate $7.5 \mathrm{~g}$; Fe $10 \mathrm{mg}$; Mn $0.1 \mathrm{mg}$. pH 5.5-8.5. Formulation by Gibbons and collaborators (KONIG; STETER, 1994), henceforth named Gibbons agar.

- Cod-milk agar made with cod fish broth basis $100 \mathrm{~mL}$; sterile low-fat milk $100 \mathrm{~mL}$; ClNa $20 \mathrm{~g}$; Agar $3.2 \mathrm{~g}$. The cod fish broth basis was prepared with $1000 \mathrm{~mL}$ of filtered cod fish broth; peptone $1 \mathrm{~g} ; \mathrm{NaCl} 200 \mathrm{~g}$. $\mathrm{pH} 8.2$ (EIMHJELLEN, 1961); henceforth named CMA.

The following media were modified and the results of their behavior are shown in this work:

- Agar-milk composed by yeast extract $3 \mathrm{~g}$; Peptone $5 \mathrm{~g}$; low-fat milk $100 \mathrm{~mL}$; agar $20 \mathrm{~g}$ (INTERNATIONAL DAIRY FEDERATION, 1974). This medium is normally used to observe the proteolytic characteristic in eubacteria. Previous research work have shown a very good growth of extreme halophilic bacteria in this medium added with $20 \% \mathrm{ClNa}$, hereafter named SAM (RAMIREZ et al., 2001). Thus, taking into account Konig and Steter's (1994) proposition, in this work the SAM medium was used with the addition of salts such as $\mathrm{MgSO}_{4}$ and $\mathrm{KCl}$, which improve the development of halophilic microorganisms. For practical purposes, this medium was named SAMm (SAM modified). 


\section{Preparation:}

Yeast extract, peptone and agar powder are hydrated with water and homogenized in a glass flask. The salts $\left(\mathrm{NaCl}, \mathrm{MgSO}_{4}\right.$ and $\mathrm{KCl}$ ) are dissolved in another glass flask with water. Both preparations are individually sterilized and time is give until the temperature lowers to $80^{\circ} \mathrm{C}$. When this temperature is achieved, the contents of both flasks are mixed to obtain the base agar.

On the other hand, the low fat milk powder is solubilized in sterile water at room temperature. Then, the reconstituted milk is heated until $35^{\circ} \mathrm{C}$. The agar base and the reconstituted heated milk are mixed to obtain the SAMm medium.

- IRAM plus milk, composed as IRAM plus $10 \% \mathrm{w} / \mathrm{v}$ of reconstituted sterile low-fat powdered milk, henceforth Milk-IRAM (M-IRAM).

- Gibbons plus milk to which $10 \% \mathrm{w} / \mathrm{v}$ of reconstituted sterile low-fat powdered milk was added, from now on Milk-Gibbons (M-Gibbons).

- These media

According to Bergey's Manual (KONIG; STETER, 1994), all media were raised to $20 \% \mathrm{w} / \mathrm{v}$ of $\mathrm{NaCl}$ to improve growth at its best.

Growth measurements were determined by plate counting. Growth experiments were performed in triplicate (Jay, 2005), incubated at $37{ }^{\circ} \mathrm{C}$ until obtaining pink pigments, indicating positive results INSTITUTO ARGENTINO DE NORMALIZACIÓN Y CERTIFICACION (1988).

To verify the growth rate, a $10^{-1}$ dilution was used; taking into account the initial load of inoculums, the counting was obtained from $10^{-6}$ dilution in each medium.

Salted ripened samples:

The excess of salt in ripened anchovy was eliminated through paper filtering before homogenization. The homogenate was prepared with $10 \mathrm{~g}$ of salted ripened anchovy, in $90 \mathrm{~mL}$ of salt broth (dilute $10^{-1}$ ).

Fillet in oil samples:

The excess of oil in fillets was eliminated through paper filtering before homogenization.

The homogenate was prepared with $10 \mathrm{~g}$ of fillet, in $90 \mathrm{~mL}$ of salt broth (dilute $10^{-1}$ ).

\section{Dilutions:}

$1 \mathrm{~mL}$ of $10^{-1}$ dilution was added to $9 \mathrm{~mL}$ of sterile salt broth ( $10^{-2}$ dilution) and so on, successively. The concentration diminished tenfold for each successive dilution (MOSSEL et al., 2003).

\section{Laboratory strains:}

The strains were previously isolated from salted ripened fish, identified by means of biochemical test suggested in the Bergey's Manual (KONIG; STETER, 1994), and kept in our laboratory. These strains were: Haloarcula spp. (proteolytic) and Halococcus spp (non-proteolytic). These strains were inoculated in Gibbons broth, incubated for 4-6 days at $37^{\circ} \mathrm{C}$, and used for growth studies.

\section{Growth studies:}

$0.1 \mathrm{~mL}$ of fresh culture or salted ripened sample was inoculated on surface on Petri dish with 18-20 mL of fresh agar medium.

Statistical analysis:

The results were analyzed by the analysis of variance (ANOVA) in two ways, Duncan's test, $(\mathrm{p} \leq 0.05)$. All statistics were obtained using STRATGRAFICS SOFTWARE (Manugistics Inc., Rocville, USA).

\section{Results}

The results obtained from experiences carried out with the proteolytic strain Haloarcula spp. and the-non proteolytic strain Halococcus spp. are shown in Figures 1 and 2, respectively.

Although in Figure 1 it can be seen that Haloarcula spp., proteolytic strain, required the lowest time for grow in SAMm medium, no significant differences were observed.

Considering Halococcus spp., non-proteolytic strain, it can be observed that the fastest growth was obtained in CMA and SAMm media, as is showed in Figure 2, with significant differences compared to the other media.

The growth required time of Haloarcula spp. and Halococcus spp. are similar in the SAMm medium - around

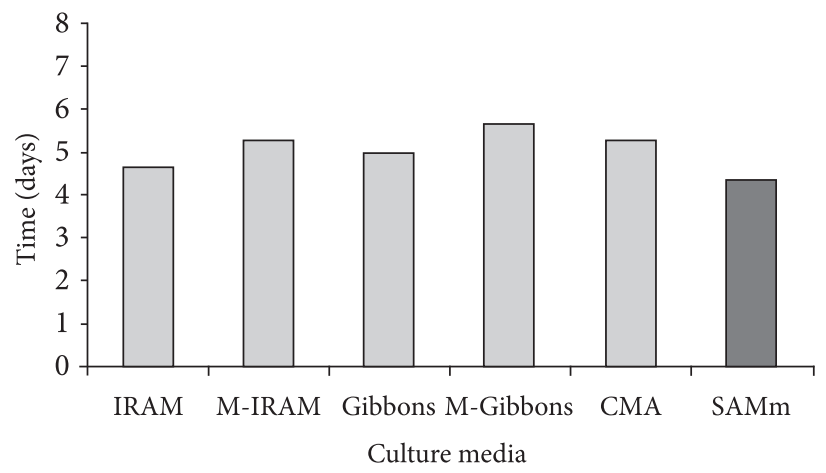

Figure 1. Proteolytic strain, Haloarcula spp. Time required obtaining positive results in different media.

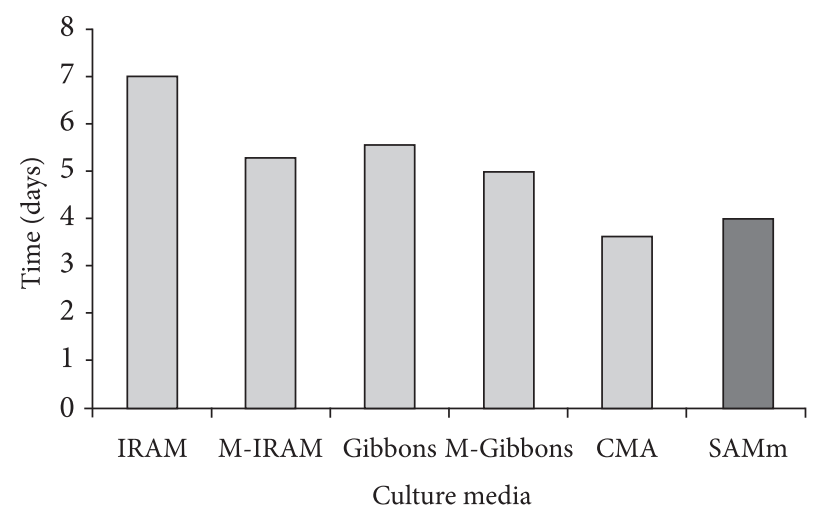

Figure 2. Non-proteolytic strain, Halococcus spp. Time required obtaining positive results in different media. 
4 days. Similarly, this fact occurs with these strains in M-IRAM, Gibbons and M-Gibbons, but in these media, it was necessary one more day of incubation (around 5 days) when compared to the SAMm medium. The growth in IRAM and CMA media presented a random behaviour, depending on the strain assayed.

These results show that the SAMm medium was adequate to the growth of those assayed strains with very good performances. The enrichment with salts realized in the SAMm medium are fundamental, since, according to Dennis and Shimmin (1997) and Omer et al. (2003), the physiology of the extremely halophilic bacteria is definitively modified in order to grow and survive in environments with high concentrations of different ions, such as $\mathrm{K}^{+}, \mathrm{Mg}^{++}$and $\mathrm{Cl}^{-}$. Therefore, this organisms have a limited aptitude to adapt to changes in the osmolarity of the environments and their growth is restricted by very high saline concentrations (OREN, 1999). These kinds of microorganisms have developed the possibility of a massive accumulation of compounds on their cytoplasm to compensate the osmotic pressure of the environment. This mechanism, named "salt-in", is typical of the Arqueas, which accumulate inorganic ions in their cytoplasm, mainly $\mathrm{K}^{+}$and $\mathrm{Cl}^{-}$(WOESE, 2005). This fact is not modified by the proteolytic characteristic of the strain, which does not affect its growth.

Figures 3 and 4 show the results obtained with samples coming from salting factories (salted mature anchovy and anchovy fillets in oil). Regarding the growth rate in different media, a significant difference was observed in the anchovy fillet oil $(\mathrm{p}<0.001)$. First positive results were obtained in the SAMm medium with a maximum period of 6 days to the outcome. In the M-IRAM and M-Gibbons agar media, the growth was observed in a shorter period of time when compared to the same ones without milk (Figure 3).

The sample of salted ripened anchovy showed that there was a significant difference from the diverse media $(p<0.005)$. In the SAMm medium, positive results were obtained in seven days, being necessary more days for the Gibbons, M-Gibbons, IRAM, M-IRAM media (eight to nine days). The CMA medium required several more days (12). No significant differences were observed during growth in media with and without milk (Figure 4).

In anchovy fillet in oil (final product), since the product has concluded its maturation (YEANNES, 2006), two

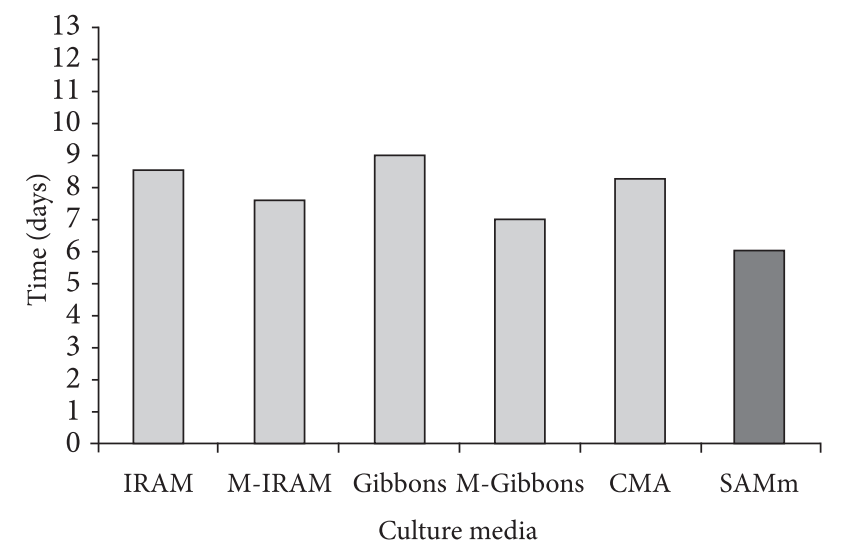

Figure 3. Time required obtaining positive results in cultures performed with anchovy fillet in oil. different strains were presented (Micrococcus halobius and Haloferax gibbonsii) and in the sample of salted ripening anchovy, five different strains were identified (Micrococcus halobius, Haloferax gibbonsii, Halobacterium spp., Micrococcus varians and Halobacterium salinarum) (FELIX et al., 2007b, 2008).- It was observed that the period of time needed for obtaining a positive result in the ripened anchovy contenting five strains was greater than the one necessary in the anchovy fillet in oil that had only two strains. The natural inter-specific competence established between the microorganisms could have been the cause of the longer growth period time observed in these samples in comparison with the pure strains and between them.

Counting obtained with pure strains (Haloarcula spp. and Halococcus spp.) in different culture media in the same incubation period of time are shown in Figures 5 and 6.

The differences find out in the counting of Haloarcula spp. in all media were smaller than a logarithmic order (Figure 5).

The best counting for Halococcus spp. strains were obtained with M-IRAM, Gibbons and SAMm (Figure 6).

The results obtained indicate that the formulated medium had a good performance. It offered the microorganism good growth possibility at a shorter period of time. This could represent an additional benefit considering the long time of incubation for these bacteria.

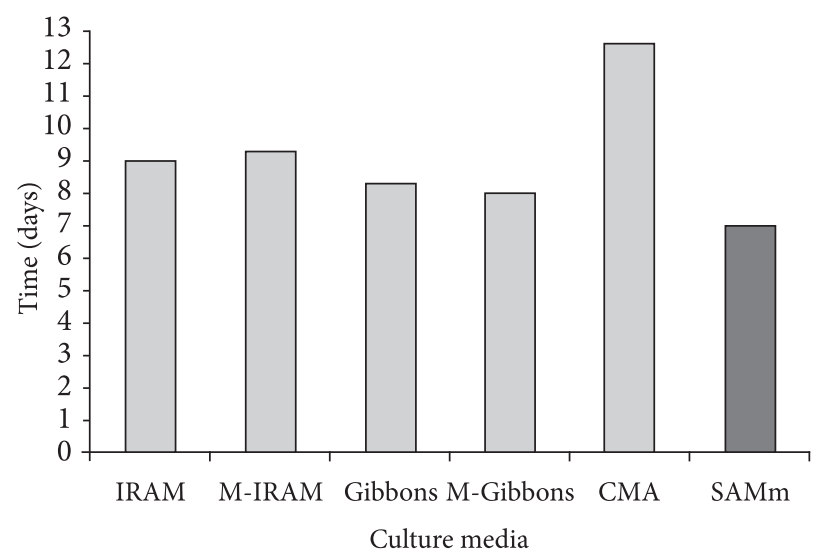

Figure 4. Time required obtaining positive results in cultures performed with salted mature anchovy.

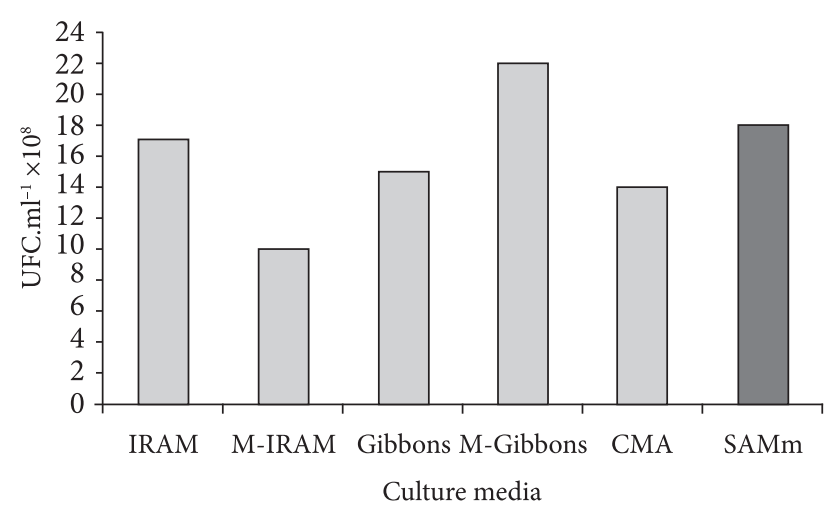

Figure 5. Haloarcula spp. (proteolytic strain). Counting of UFC. $\mathrm{mL}^{-1}$ in different culture media. 


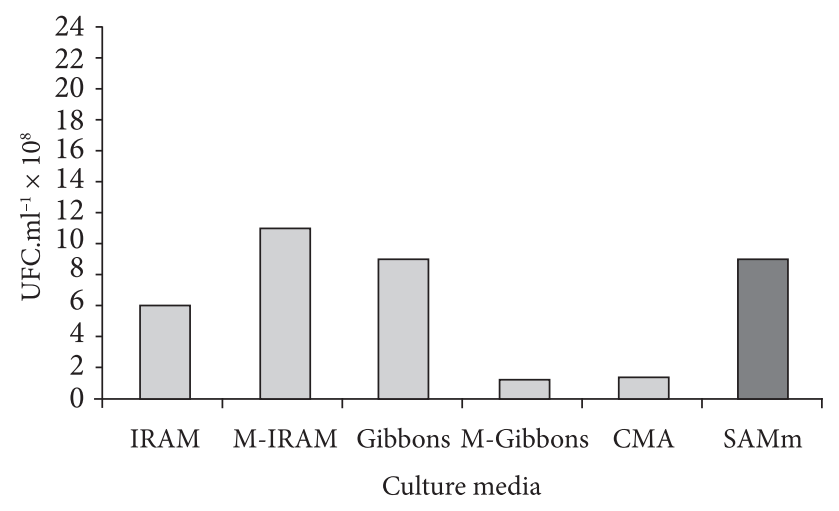

Figure 6. Halococcus spp. (non-proteolytic). Counting of UFC. $\mathrm{mL}^{-1}$ in different culture media.

The results obtained failed to determine whether the influence of the milk addition to the media was a benefit.

\section{Conclusions}

According to the results, it was possible to obtain positive results through the SAMm medium two or three days earlier than through the traditional media. The SAMm medium showed similar or higher counting values when compared to the traditional media.

Consequently, the SAMm medium can be considered an alternative to those media traditionally used in the study of these bacteria.

Likewise, it was observed that the pure strain produced positive results earlier than the mixed strain. Therefore, it is important to consider this matter to allow a longer incubation time in the control of fish products samples.

Concerning the milk addition, the results obtained failed to determine its influence on the growth time and counting.

\section{Acknowledgements}

The authors are grateful to the 'Universidad Nacional de Mar del Plata' (UNMDP) and to the 'Consejo Nacional de Investigaciones Científicas y Técnicas' (CONICET) for the support and sponsorship.

\section{References}

BALLABENE, A. C.; CAMPERO, C. M.; ELBUSTO, C. A. Gérmenes halófilos aislados de pescados salados y saladeros de Mar del Plata y su área. Apartado Revista de Medicina Veterinaria, v. 60, n. 3, p. 3-8. 1979.

BARAT, J. et al. Cod salting manufacturing analysis. Food Research International, v. 36, n. 5, p. 447-453. 2003.http://dx.doi.org/10.1016/ S0963-9969(02)00178-3

BELLAGHA, S. et al. Studies on salting and drying of sardine (Sardinella aurita): Experimental kinetics and modelling. Journal of Food Engineering, v. 78, n. 3, p. 947-952. 2007.http://dx.doi. org/10.1016/j.jfoodeng.2005.12.008

CZERNER, M.; YEANNES, M.I. Evolução da microflora durante o amadurecimento de anchova (E. anchova) In:. XI CONGRESSO ARGENTINO DE CIÊNCIA. e TECNOLOGIA DE ALIMENTOS;...
II SIMPÓSIO INTERNACIONAL SOBRE NOVAS TECNOLOGIAS, 2007, Buenos Aires. Anais Buenos Aires, 2007.

DENNIS, P. P.; SHIMMIN, L. C. Evolutionary divergence and salinity-mediated selection in halophilic archaea.Microbiology and Molecular Biology Reviews, v. 61, n. 1, p. 90-104. 1997. PMid:9106366. PMCid:232602.

DORÉ, B. Ensuring reafood safety. In: BORRENSEN, T. (Ed.). Improving seafood products for the consumer. New York:CRC LLC, 2008.p. 185-192.

EIMHJELLEN, K. Isolation of extremely halophilic bacteria. 1961.

ELSZTEIN, C. et al. Autoproteolytic activation of Natronococcus occultus extracellular serine protease. Journal of Basic Microbiology, v. 41, p. 319-327. 2001.http://dx.doi.org/10.1002/15214028(200112)41:6\%3C319::AID-JOBM319\%3E3.0.CO;2-8

FELIX, M. et al. Incidence of Different Genus of Halophilic Arqueobacteria in Samples of Matured Salted Anchovy (Engraulis anchoita) Biocell, v. 28, n. 2, p. 226, 2004.

FELIX, M. et al. Identification of microorganism in salt used in process of food conservation. Biocell,v. 31, n. 1, p. 120, 2007 a.

FELIX, M. et al. Evaluación microbiológica de anchoíta (Engraullis anchoíta) salada madurada y filetes en aceite. In: CONGRESO ROSARINO, 10.; REUNIÓN ANUAL DE LA SOCIEDAD DE BIOLOGÍA DE ROSARIO, 28., 2008, Rosario. Anais... Rosario, 2008.

FELIX, M.; RAMIREZ, E.; YEANNES, M.I. Comportamiento de Halococcus morruhae en distintos medios de cultivo. IX Congreso Argentino de Ciencia y Tecnología de Alimentos. Puerto Madero. Buenos Aires. Argentina. 7 al 9 de agosto de 2002.

FELIX, M.;RAMIREZ, E. E.; YEANNES, M. I. Bacterias halófilas extremas deteriorantes en anchoíta salada. Revista de Ciencias Agrarias y de Tecnología de Alimentos, v. 24, $2007 \mathrm{~b}$.

FELIX, M. et al. Halococcus morruhae en productos de anchoíta (Engraulis anchoita) Caracterización halofilica. In: CONGRESO INTERNACIONAL DEL CARIBE SOBRE HIGIENE, 1.; CALIDAD EN LA AGRICULTURA Y ALIMENTACIÓN. SIMPOSIO INTERNACIONAL SOBRE EVALUACIÓN HIGIÉNICA Y DE LA CALIDAD EN LA INDUSTRIA AGROALIMENTARIA Y HOTELERA, 2005, La Habana. Anais...La Habana: ALACCTA, ACTAC, 2005.

FUSELLI, S. et al. Microbiological study of marination process of anchovy ( $E$. anchoita). Lebbensmittel- Wissenchaft und Technologie, v. 27, p. 214-218, 1994. http://dx.doi.org/10.1300/ J030v12n01_04

FUSELLI, S. R. et al. A typical Microorganisms in Cold Marinated Anchovies (Engraulis anchoita) Filled with Corn Oil and Spices. Journal of Aquatic Food Product Technology, v. 12, n. 1, p. 5565, 2003.

HERNANDEZ-HERRERO, M. et al. Protein hydrolysis and proteinase activity during the ripening of salted anchovy (Engraulis encrasicholus l.). A microassay method for determining the protein hydrolysis. Journal of Agricultural and Food Chemistry, v. 47, n. 8, p. 3319-3324. 1999.http://dx.doi.org/10.1021/jf980809j

HUSS, H. H. Assurance of seafood quality. Roma: FAO, 1994.(FAO Fisheries Technical paper, n. 334).

INSTITUTO ARGENTINO DE NORMALIZACIÓN Y CERTIFICACIÓN - IRAM. IRAM 15.139. Productos de la Industria Pesquera: Método para la determinación de microorganismos halófilos extremos. Buenos Aires: IRAM, 1988.

INTERNATIONAL DAIRY FEDERATION - FIL/IDF. Determinación de microorganismos lipolíticos de la manteca.FIL/IDF,1974. 
JAY, J.M.; LOESSNER, M.J.; GOLEEN, D.A. Food microbiology. 7th ed. New York: Springer, 2005.

KONIG, H.; STETER, K. O. Archaebacteria. In STALEY, J. T. et al. (Eds) Bergey`s Manual of Systematic Bacterology, vol II. Baltimore: Williams and Wilkins Co, 1989. Section 25, p. 2171-2173.

LEE, R. J.; RANGDALE, R. E. Bacterial pathogens in seafood. . In: BORRENSEN, T. (Ed.). Improving seafood products for the consumer. New York: CRC LLC, 2008. p. 247- 282. http://dx.doi. org/10.1533/9781845694586.3.247

SORTE, E. JAGER, M. Os conservantes individual. In: Lück, E., Jager, M. Antimicrobiana Aditivos Alimentares: Características, Usos, Effects. 2 ed. New York: Springer Ed, 1997. p.67-72.

MADUREIRA, L. et al. Use of wild fish and/or other Aquatic Species to Feed. Case Study: South American Anchovy (Engraulis anchoita). In: FOOD AND AGRICULTURAL ORGANIZATION OF THE UNITED NATIONS - FAO(Org.). Towards Sustainable Aquaculture: Selected Issues and Guidelines.Rome: FAO, 2007.v. 466, p. 1-29.(FAO Fisheries Technical Paper).

MONTERO C. et al. Physical Map of a 257 Kilobase-Pairs Region from the Genome of the Archaebacterium Halococcus saccharolyticus. Current Microbiology, v. 23, p. 299-302, 1991.http://dx.doi. org/10.1007/BF02104129

MOSSEL D.A.A.; MORENO GARCÍA, B.; STRUIJK, C.B. Microbiología de los Alimentos.2. ed. Acribia: Zaragoza, 2003.

OMER, A.D. et al. RNA-modifying machines in archaea.Molecular microbiology, v. 48, n. 3, p. 617-629. 2003. PMid:12694609.http:// dx.doi.org/10.1046/j.1365-2958.2003.03483.x

OREN A. Bioenergetic aspectof halophilism. Microbiology and Molecular Biology Reviews, v. 63, p. 334-348, 1999.PMid:10357854. PMCid:98969.

RAMIREZ, E. et al. Effect of milk addition in the culture medium on the growth of halophilic extremes bacteria.Biocell, v. 25, n. 2, p. 223, 2001.

RAMIREZ, N.; SERRANO, J.; SANDOVAL, T. Microorganismos extremófilos. Actinomicetos halófilos en México. Revista Mexicana de Ciencias Farmacéuticas, v. 37, n. 3, 2006.

SÁNCHEZ LEAL, L. C.; ARGUELLO ARIAS, H. Capacidad de bacterias halófilas para capturar sodio in Vitro y su posible aplicación en bioremediación en suelos salinos-sódicos. NOVA, v. 4, n. 6, p. 19-32, 2006.

SCHMIDT, F.; CARCIOFI, B.; LAURINDO, J. Application of diffusive and empirical models to hydration, dehydration and salt gain during osmotic treatment of chicken breast cuts. Journal of Food Engineering, v. 9, n. 4, p. 553-559, 2009.http://dx.doi.org/10.1016/j. jfoodeng.2008.10.003

VENTOSA, A.; et al. Proposal to transfer Halococcus turkmenicus, Halobacterium trapanicum JCM 9743 and Strain GSL-11 to Haloterrigena turkmenica gen. nov.; comb. nov. International Journal of Systematic Bacteriology, v. 49, p. 131-136, 1999. PMid:10028254.http://dx.doi.org/10.1099/00207713-49-1-131

WANG, D.; TANG, J.; CORREIA, L. Salt diffusivities and salt diffusion in farmed Atlantic salmon muscle as influenced by rigor mortis. Journal of Food Engineering, v. 43, n. 2, p. 115-123, 2000. http:// dx.doi.org/10.1016/S0260-8774(99)00140-5

WOESE, C. R. Interpreting the universal phylogenetic tree. Proceedings of the National Academy of Sciences of the United States of America,v. 97, n. 15, p. 8392-8396, 2000.http://dx.doi. org/10.1073/pnas.97.15.8392

WOESE, C. R. The archaeal concept and the world it lives in: a retrospective. Discoveries in Photosynthesis, v. 20, p. 1111-1120, 2005.http://dx.doi.org/10.1007/1-4020-3324-9-99

WOESE, C. et al. A natural system of organisms: proposal for the domains Archaea, Bacteria, and Eucarya.Proceedings of the National Academy of Sciences of the United States of America, v. 87, n. 12 , p. $4576-4579,1990 . h$ ttp://dx.doi.org/10.1073/ pnas.87.12.4576

YEANNES, M. I. Aspectos Científicos y Tecnológicos en Preservas de Productos Pesqueros. Buenos Aires: Facultad de Ciencias Agrarias, Centro de Altos Estudios “Jorge Gándara”, 2006.

YEANNES, M. I. CASALES, M. R. Estudio de las variables de proceso de marinados de anchoíta (E. anchoíta). Alimentaria. Revista de Higiene y Tecnología Alimentaria,n. 262, p. 87- 91, 1995.

YEANNES, M. I.; CASALES, M. R. Modifications in the chemical compounds and sensorial attributes of Engraulis anchoita fillet during brining and marinating stages. Ciencia e Tecnología de Alimentos, v. 28, n. 4, p. 798-803, 2008.http://dx.doi.org/10.1590/ S0101-20612008000400006

YEANNES, M. I. et al. Incidencia y géneros más hallados en anchoita salada de bacterias Halófilas extremas deteriorantes. In: CONCRESO ARGENTINO DE CIENCIA Y TECNOLOGÍA DE ALIMENTOS - CYTAL, 10; SIMPOSIO INTERNACIONAL DE NUEVAS TECNOLOGIAS, 1., 2005, Mar del Plata.Anais... Mar del Plata:Asociación Argentina de Tecnólogos Alimentarios,2005.n. 18 , p. 45. 